\title{
Turkish parents' management of childhood fever: A cross-sectional survey using the PFMS-TR
}

\author{
Nursan D. Cinar, RN, PhD ${ }^{a, 1}$ \\ Insaf Altun, RN, PhD ${ }^{\text {b, } 2}$ \\ Sevin Altınkaynak, RN, PhD ${ }^{a, 1}$ \\ Anne Walsh, RN, PhD ${ }^{c, *}$
}
a Department of Child Health Nursing, School of Health Sciences, Sakarya University, Sakarya 54187, Turkey
b Department of Fundamentals in Nursing, High School of Health, Kocaeli University, Umuttepe, Kocaeli 41380, Turkey
c School of Nursing, Institute of Health and Biomedical Innovation, Queensland University of Technology, Brisbane, Queensland 4059, Australia

Received 15 February 2013; received in revised form 11 September 2013; accepted 15 October 2013

\section{KEYWORDS}

Fever management;

Child;

Parent;

Parent Fever

Management Scale

(PFMS);

Turkey;

PFMS-TR

\begin{abstract}
Summary
Background: To explore Turkish parents' practices in childhood fever management.

Methods: A cross-sectional study with 205 randomly selected Turkish parents of febrile children 6-months to 5-years from the paediatric hospital and two family health centres in Sakarya, Turkey in 2009. Data explored general fever management practices on the 8-item Parents' Fever Management Scale - Turkish version (5-point Liket scale; $1=$ never to 5 =always) and socio-demographics.

Results: Parents wanted to know their child's temperature $(61.5 \%)$, took temperatures $(60 \%)$, slept in the same room (58.5\%) and sought medical advice (53.7\%). Non-evidence-basedpractices included over-the-counter medications (42.4\%); waking children during the night for fever reducing medication (33.2\%). Evidence-based-practice ensured febrile children had plenty to drink (30.2\%) and febrile children were checked during the night (59\%).
\end{abstract}

\footnotetext{
* Corresponding author. Tel.: +61 73138 3905; fax: +61 731383814 .

E-mail addresses: ndede@sakarya.edu.tr (N.D. Cinar), ialtun@kocaeli.edu.tr (i. Altun), saltinkaynak@sakarya.edu.tr (S. Altınkaynak), am.walsh@qut.edu.au (A. Walsh).

1 Tel.: +90 05324982730; fax: +902642956602900.

2 Fax: +902624541925900.
}

1574-6267/\$ - see front matter ๔ 2013 College of Emergency Nursing Australasia Ltd. Published by Elsevier Ltd. All rights reserved. http://dx.doi.org/10.1016/j.aenj.2013.10.002 
Conclusions: Parents' reports indicate high levels of concern about fever, overuse of overthe-counter medications and health services. Practices increase parents' burden of care, are disruptive of family life and lead to parental fatigue. The study confirms the appropriateness and applicability of the fever management instrument, a simple tool to incorporate into assessment of febrile children, in identifying Turkish parents' fever management practice.

(c) 2013 College of Emergency Nursing Australasia Ltd. Published by Elsevier Ltd. All rights reserved.

\section{What is already known about this topic?}

- Parents internationally are concerned about childhood fever.

- Antipyretics are the preferred method of managing childhood fever, aiming to normalise temperature thereby reducing harmful outcomes from fever.

- Parents need to receive consistent evidence-based information.

\section{What this paper adds?}

- The Turkish version of the Parent Fever Management Scale (PFMS-TR) is an effective means of identifying Turkish parents' evidence and non-evidence-based childhood, fever management practices.

- This 8-item scale identifies areas for parent education to reduce their burden of care during febrile episodes as well as reducing unnecessary over-thecounter medication and overuse of health services.

\section{Introduction}

Fever, a common symptom in children, is one of the major concerns of parents of febrile children and a key factor in their use of emergency rooms and community based medical practitioners for advice; contributing to overuse of health resources. ${ }^{1,2}$ Care seeking is strongly associated with parents' perceptions and representations of childhood fever. $^{3,4}$ Turkish parents' fever management practices have not been explored in detail. Neither has the applicability of a Turkish version (PFMS-TR) ${ }^{5}$ of a brief fever management instrument Parents' Fever Management Scale (PFMS) ${ }^{6}$ in identifying areas for parent fever management education to reduce the unnecessary burden of caregivers and overuse of health care resources when a child has a febrile illness.

Caring for a febrile child is an integral aspect of parents or caregivers life that is often misunderstood and incorrectly managed. . $^{3,4}$ Inexperienced parents report feeling particularly anxious and helpless and often find the severity of the illness difficult to judge.$^{8-11}$ For consistent rational fever management it is essential parents and caregivers have appropriate knowledge and positive attitudes towards the benefits of fever. ${ }^{12,13}$ A clear understanding of community perceptions and attitudes towards childhood illness is important in developing appropriate interventions. To ensure this, there is a need to understand the perceptions and representations of parents and caregivers. This aspect of parenting is receiving increasing attention in both the academic literature, the media and advertising of antipyretics, particularly in the winter months, regarding the prominent role of childhood fever in the use and overuse of healthcare services and over-the-counter medications. ${ }^{5,22}$

Recent studies in Turkey identify parents' fear of fever with $83-97 \%$ believing fever harmful, ${ }^{14,15}$ and harmful if left untreated (84\%). ${ }^{7}$ Turkish parents, similarly to others internationally, believed untreated fever could cause febrile convulsions (84\%), brain damage $(10.5 \%)^{7}$ or death (12\%). ${ }^{14}$ Esenay et al. ${ }^{16}$ found phobic behaviours that could adversely affect children's health and lead to inappropriate fever management practices. Most Turkish mothers surveyed $(86.5 \%)$ took their child's temperature at less than hourly intervals, and $95.8 \%$ stayed awake all night to track the child's fever. ${ }^{16}$ It is timely to identify phobic and burdensome practices with a short, targeted instrument to enable parent education targeting individual parents' needs.

The aims of this study were to (1) survey the childhood fever management practices of Turkish parents seeking medical assistance for a febrile child using the Turkish version of the PFMS ${ }^{6}$ (PFMS-TR) ${ }^{5}$ and (2) identify differences in practices between socio-demographic variables. Findings will assist health professionals in identifying parents fever management practices and act as a guide to promoting appropriate targeted measures to improve Turkish parents' childhood fever management.

\section{Materials and methods}

\section{Design}

A cross-sectional study was undertaken in the state of Sakarya, Turkey, during September and October 2009.

\section{Participants}

Two hundred and five parents, selected by simple random and stratified weighted sampling methods, were recruited from one paediatric hospital and two family health centres located in central Sakarya, Turkey on Tuesday and Thursday of each week during the data collection period. The sample was recruited from parents presenting at these centres for a febrile illnesses in a child aged between six months and five years. All parents volunteered to participate in an individual interview following their child's febrile illness being independently triaged as non-emergent. Eligibility criteria were Turkish ethnicity and the ability to read and write Turkish, 18 years of age or older and the primary caregiver of the febrile child aged between six months and five years. 


\section{Data collection}

One-to-one interviews were used for data collection at the participating hospital and family health centres. The original Parent Fever Management Scale (PFMS) ${ }^{6}$ for measuring parents' practice about childhood fever management was developed by Walsh et al. ${ }^{6}$ in an Australian population and tested for content validity by a panel of Australian experts in paediatrics and instrument development. A detailed explanation of the instrument development is available in the article by Walsh et al. ${ }^{6}$ The Turkish language version by Altun et al. (PFMS-TR $)^{5}$ was examined by three experts, a paediatrician, an academic paediatric nurse and an Academic expert in Fundamental Nursing. Minor changes were made and the instrument piloted with 10 parents, not included in the main study, for ease of understanding, and was found satisfactory. Construct/convergent validity was confirmed through confirmatory factor analysis $(\alpha=0.80)$. See Altun et al. ${ }^{5}$ for more detailed description.

The PFMS-TR consists of the original eight items assessed in 5-point Likert-type format $(1=$ never, 2 = rarely, 3 =sometimes, 4 =mostly, 5 =always). The scale has a possible range of $8-40$, with higher scores indicating higher levels of practices and therefore more concern about fever, indicating fever phobia, and greater parental burden of care during their child's febrile illness. The PFMS-TR is presented in Table 1. Socio-demographical variables, such as the respondent's age, sex, marital status, number of children, geographical location of their home, years of education and healthcare insurance coverage, were included in the Turkish instrument.

\section{Ethical considerations}

Institutional approval was obtained from the Ethics Committee of Sakarya University. Participants gave verbal consent for the use of their data for the purpose of this study.

\section{Data analysis}

The Statistical Package for Social Sciences (Version 15.0.1) ${ }^{17}$ was used to compute demographic frequencies and descriptive statistics. Internal consistency and homogeneity between the PFMS-TR items were calculated using Cronbach's alpha coefficient. ${ }^{18}$ PFMS-TR mean and standard deviation (SD) were calculated for items and total score. Findings were then examined to determine differences in PFMS-TR in responses by demographic variables using Chi Square, $t$-tests and ANOVA as appropriate. Significant Chi Square tests were examined using Fishers Exact Test. Where significant ANOVA results were discovered Post Hoc Analysis using and Tukey's HSD were conducted.

\section{Results}

\section{Demographic data}

Most participants, $91.2 \%(n=187)$, were the mother of the febrile child; all were married $(100 \%)$ and more than half, $57.6 \%(n=118)$, were younger than 30 years of age. Most were the parent of one or two children $(80.5 \%, n=165)$. The majority of mothers were homemakers and fathers employed. Mothers and fathers were equally likely to have more than eight years $(54.2 \%)(n=101)$, or eight or less years of schooling $(53.6 \%)(n=110)$. Most parents had healthcare insurance coverage $(81.0 \% ; n=166)$; half lived in a village/small town $(50.7 \%, n=104)$ with the remainder living in a city/major city. Demographics are reported in Table 2. Significant demographic differences were found between parents' level of education: mothers $(p=0.01)$ and fathers $(p=0.01)$ and whether or not they had health insurance $(p=0.01)$.

\section{PFMS-TR}

Internal reliability of the PFMS-TR scale was strong for the 8 items $(\alpha=0.79) .{ }^{19}$ The mean total score was $33.54 \pm 4.98$ (potential 8-40) indicating a high level of activities that would interfere with daily life with a focus on nonevidence-based practices, e.g., child's temperature. This was reinforced when item means were examined. Item 2, wanting to know what the child's temperature had the highest mean $(4.44 \pm 0.81)$. Only two items had means below 4.00; item 7, waking children during the night for medication to reduce fever (non-evidence-based) $(3.74 \pm 1.21)$ and item 3, making sure febrile children have plenty to drink (3.81 \pm 1.08$)$ (evidence-based). Evidence-based items, items 3 and 5 , had means of $3.81 \pm 1.08$ and $4.41 \pm 0.83$, respectively. The remaining items indicate nonevidence-based practices and ranged from $3.74 \pm 1.21$ to $4.44 \pm 0.81$ with the greatest variability in responses relating to item 7 , waking febrile children for an antipyretic.

\section{Burden of caring for a febrile child}

When their child was febrile the majority of parents mostly/always checked on them during the night (87.3\%); liked to know what their temperature was (86.9\%); slept in the same room as them $(84.8 \%)$; took them to the doctor $(83.5 \%)$; took their temperature $(81.0 \%)$ and used over the counter medication to reduce the fever (76.1\%). Sixtyseven percent $(66.8 \%)$ made sure the febrile child had plenty to drink; similar percentages of parents (63.4\%) woke their febrile child during the night for medication to reduce their fever. See Table 1 for parents reported practices.

\section{PFMS-TR analysis by significantly different demographic variables}

When the total PFMS-TR score and specific items were analysed by socio-demographic variables there were significant differences in a number of areas, recruitment, hometown and maternal education. Place of recruitment made a significant difference to parents' total PFMS-TR score with higher means reported from hospitals than family health centres. When specific items were examined, it was found that parents from the hospital setting were significantly more likely to report evidence-based practices, ensuring their child had plenty to drink and checking on the child during the night. See Table 3 for means, standard deviations. 
Table 1 Parent' practices according to the Turkish Parent Fever Management Scale (PFMS-T) $n=205$.

\begin{tabular}{|c|c|c|c|c|c|c|c|}
\hline & When my child has a fever I generally & $\begin{array}{l}\text { Never } \\
\%\end{array}$ & $\begin{array}{l}\text { Rarely } \\
\%\end{array}$ & $\begin{array}{l}\text { Sometimes } \\
\%\end{array}$ & $\begin{array}{l}\text { Mostly } \\
\%\end{array}$ & $\begin{array}{l}\text { Always } \\
\%\end{array}$ & Mean \pm SD \\
\hline 1 & Take their temperature & 3.4 & 3.4 & 12.2 & 21.0 & 60.0 & $4.30 \pm 1.03$ \\
\hline 2 & $\begin{array}{l}\text { Like to know what their temperature } \\
\text { is }\end{array}$ & 1.0 & 1.3 & 10.7 & 25.4 & 61.5 & $4.44 \pm 0.81$ \\
\hline 3 & Make sure they have plenty to drink & 6.3 & 2.4 & 24.4 & 36.6 & 30.2 & $3.81 \pm 1.08$ \\
\hline 4 & $\begin{array}{l}\text { Use over the counter medication to } \\
\text { reduce the fever }\end{array}$ & 2.0 & 1.5 & 20.5 & 33.4 & 42.4 & $4.13 \pm 0.92$ \\
\hline 5 & Check on them during the night & 1.5 & 1.5 & 9.8 & 28.3 & 59.0 & $4.41 \pm 0.83$ \\
\hline 6 & Sleep in the same room as them & 2.4 & 2.4 & 13.7 & 25.9 & 58.5 & $4.35 \pm 0.94$ \\
\hline 7 & $\begin{array}{l}\text { Wake them up during the night for } \\
\text { medication to reduce their fever }\end{array}$ & 9.3 & 3.4 & 23.9 & 30.2 & 33.2 & $3.74 \pm 1.21$ \\
\hline 8 & Take them to the doctor & 24.0 & 0.5 & 13.7 & 29.8 & 53.7 & $4.31 \pm 0.90$ \\
\hline
\end{tabular}

The size of parents' hometown had a significant influence on their fever management practices. These were significant differences dependant on parents' hometown, in relation to ensuring their child had plenty to drink $(p=0.01)$ and taking their temperature $(p=0.02)$. Those living in cities were significantly more likely to take their child's temperature $(p=0.04)$, potentially phobic practice, and ensure their child had plenty to drink $(p=0.01)$, evidence-based, than those living in a small town (see Table 3 ).
Mothers' education made a significant difference on the total score and on a number of items: taking their child's temperature, ensuring they had plenty to drink, sleeping in the same room as the child and waking febrile children for antipyretics during the night. Overall, mothers who had a university education scored higher on the total PFMS-TR $(p=0.01)$ than those with eight or less years of education, indicating greater burden of caregiving in parents with a university education. Specifically, university educated mothers

Table 2 The relationship between family characteristics and residence $N=205$.

\begin{tabular}{|c|c|c|c|c|c|c|}
\hline & \multicolumn{2}{|c|}{ Total } & \multirow{2}{*}{$\begin{array}{l}\text { Village } N=32 \\
\%\end{array}$} & \multirow{2}{*}{$\begin{array}{l}\text { Small town } N=72 \\
\%\end{array}$} & \multirow{2}{*}{$\begin{array}{l}\text { City } N=101 \\
\%\end{array}$} & \multirow[t]{2}{*}{$\chi^{2}, \mathrm{df}, p$} \\
\hline & $n$ & $\%$ & & & & \\
\hline \multicolumn{7}{|l|}{ Age } \\
\hline$\geq 30$ & 118 & 57.6 & 10.2 & 19.5 & 27.8 & \multirow{3}{*}{$\begin{array}{l}1.69, \text { df } 4 \\
p=0.79^{a}\end{array}$} \\
\hline $31-45$ & 76 & 37.1 & 4.4 & 14.1 & 18.5 & \\
\hline $46 \geq$ & 11 & 5.4 & 1.5 & 2.9 & 5.4 & \\
\hline \multicolumn{7}{|l|}{ Education of mother } \\
\hline Primary school (8 years) & 126 & 61.5 & 13.2 & 23.4 & 24.9 & \multirow{3}{*}{$\begin{array}{l}18.60, \text { df } 4, \\
p=0.01^{a}\end{array}$} \\
\hline Lysee (11 years) & 55 & 26.8 & 2.4 & 8.8 & 15.6 & \\
\hline University (13-15 years) & 24 & 11.7 & 3.7 & 8.4 & 11.8 & \\
\hline \multicolumn{7}{|l|}{ Education of father } \\
\hline Primary school (8 years) & 98 & 47.8 & 11.7 & 17.6 & 18.5 & \multirow{3}{*}{$\begin{array}{l}\text { 19.72, df } 4, \\
p=0.01\end{array}$} \\
\hline Lysee (11 years) & 58 & 28.3 & 3.4 & 11.2 & 13.7 & \\
\hline University (13-15 years) & 49 & 23.9 & 0.5 & 6.3 & 17.1 & \\
\hline \multicolumn{7}{|l|}{ Healthcare insurance } \\
\hline Yes & 166 & 81.0 & 10.2 & 27.3 & 43.4 & \multirow{2}{*}{$\begin{array}{l}8.718, \text { df } 2 \\
p=0.013\end{array}$} \\
\hline No & 39 & 19.0 & 5.4 & 7.8 & 5.9 & \\
\hline \multicolumn{7}{|c|}{ Hospital and family centre recruitment } \\
\hline Hospital & 169 & 82.4 & 13.2 & 26.8 & 42.7 & \multirow{2}{*}{$\begin{array}{l}2.86, \text { df } 2, \\
p=0.24\end{array}$} \\
\hline Family Health Centre & 36 & 17.6 & 2.4 & 8.3 & 6.8 & \\
\hline \multicolumn{7}{|l|}{ Mother's profession } \\
\hline Employed & 49 & 23.9 & 2.9 & 7.8 & 13.2 & \multirow{2}{*}{$\begin{array}{l}1.02, \text { df } 2, \\
p=0.60\end{array}$} \\
\hline Housewife & 156 & 76.1 & 12.7 & 27.3 & 36.1 & \\
\hline \multicolumn{7}{|l|}{ Father's profession } \\
\hline Employed & 201 & 98 & 15.1 & 34.1 & 48.8 & \multirow{2}{*}{$\begin{array}{l}1.02, \mathrm{df}=4 \\
p=0.60^{\mathrm{a}}\end{array}$} \\
\hline Retired & 4 & 2.0 & 0.5 & 1.0 & 0.5 & \\
\hline
\end{tabular}

\footnotetext{
a Fisher's exact test was applied.
} 
Table 3 Comparison between recruitment and residential areas.

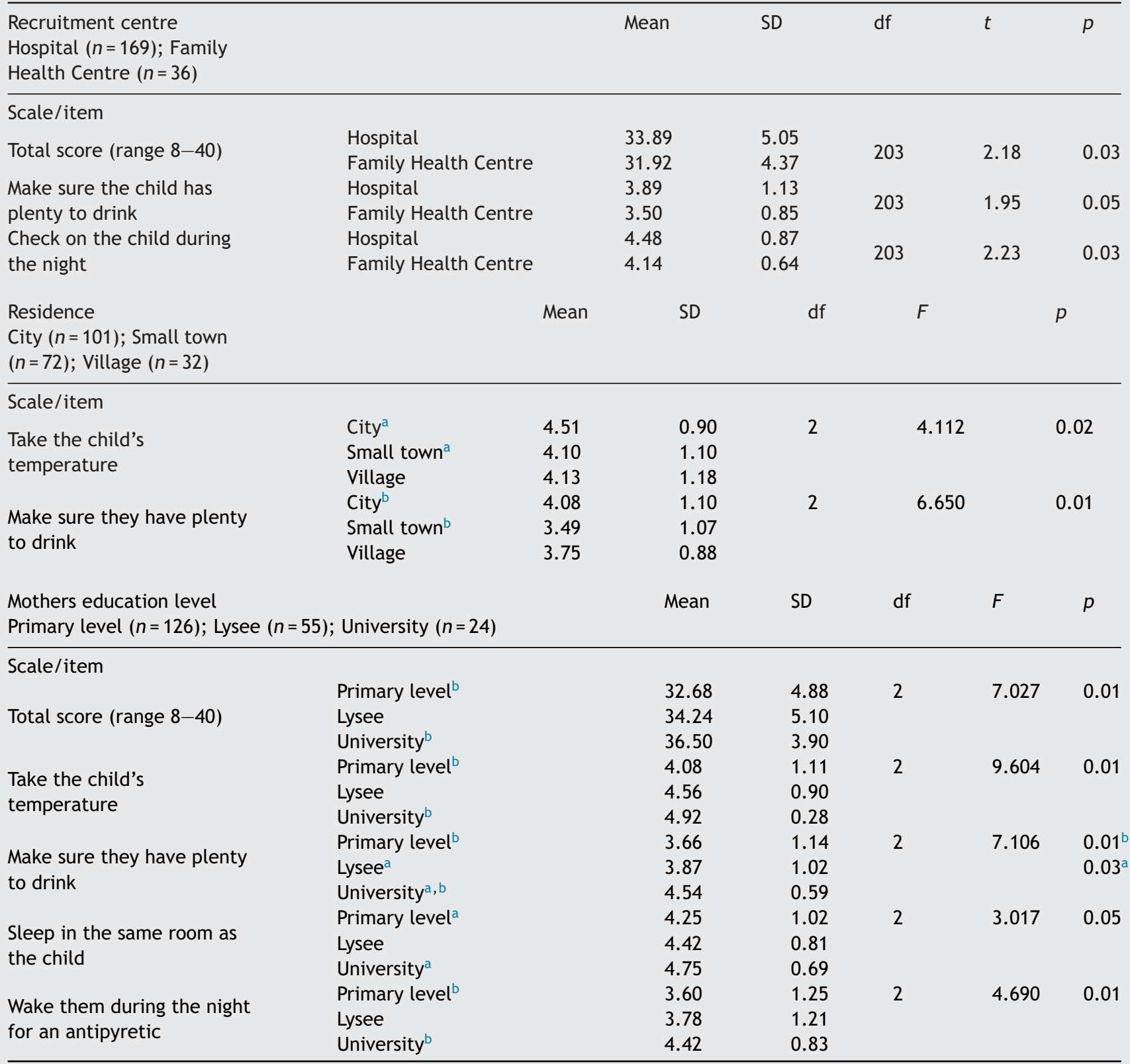

\footnotetext{
a Significant difference of $p \leq 0.05$.

b Significant difference of $p \leq 0.01$.
}

were significantly more likely to take their child's temperature $(p=0.01)$ and sleep in the same room as their febrile child $(p=0.05)$, potentially phobic non-evidencebased practices; and make sure their child had plenty to drink $(p=0.01)$, evidence-based, than those with eight years or less schooling. University educated mothers were also more likely than those with Lysee (11 years of schooling) to ensure febrile children had plenty to drink $(p=0.03)$.

\section{Discussion}

This study examined Turkish parents' fever management practices using the PFMS-TR. ${ }^{5}$ Parents overall PFMS-TR score was high. Turkish parents reported high scores on all behaviours in the PFMS-TR when their child was febrile. These findings indicate concern about fever. Parents mostly/always liked to know the child's temperature, took temperatures regularly and slept in the same room as the febrile child. Additionally, they mostly/always used antipyretics to reduce fever and woke febrile children during the night for an antipyretic; practices not based on scientific evidence. ${ }^{22}$ Evidence-based practices were reported less frequently, ensuring the febrile child had plenty to drink and checking their child during the night. ${ }^{22}$ Findings demonstrate fever phobic behaviours with a potential to overuse medical services; parents reported they mostly/always seek 
medical advice for febrile children. This study identified the need for specific targeted education dependent on sociodemographics highlighting the necessity of identifying each parent's educational needs using a quick, simple instrument.

\section{PFMS-TR}

The PFMS-TR mean was very high, 33.54 out of a potential range of 8-40 (higher score more concern), indicating that most participating Turkish parents were very active in monitoring temperature and reducing fever, behaviours indicating concern about fever. Additionally they reported practices quite intrusive into family life, such as sleeping in the same room as the febrile child. These practices may not be necessary for a simple viral febrile illness, which most childhood illnesses are. ${ }^{20}$ Findings support those of an earlier study to evaluate the PFMS in a Turkish setting where the overall PFMS-TR score was 34.52 (SD 4.60). ${ }^{5}$ Turkish parents report more fever management activities than Australian parents in the first study using the PFMS (17.20; SD 4.45; range $8-33$; potential range $7-35) .6$ Based on finding from these studies, it could be argued that in Turkey parents generally evaluate fever as harmful, more harmful than parents in Australia.

\section{Concern about temperature}

Turkish parents in our study wanted to know their child's temperature. More than half the parents always wanted to know their child's temperature $(61.5 \%)$, confirming this need was reports of always measuring the child's temperature (60\%). Findings confirm recent Turkish research ${ }^{16,21-23}$ with concerns about fever increasing over the past few years. ${ }^{7,14}$

Antipyretic use among Turkish parents in both Turkey and neighbouring countries are similar. Langer et al. ${ }^{24}$ found that Turkish mothers, living in Germany, described fever as a 'fearful' concept and identified antipyretics as the preferred method of reducing fever (93.4\%). These mothers were more likely to administer antipyretics at too frequent or incorrect doses $(46.8 \%)$ than those without these beliefs (31.3\%). ${ }^{25}$ Incorrect antipyretic dosing was common in Turkish parents presenting at an emergency department, $66.5 \%$ incorrectly dosing with paracetamol (54\% under-dosing and $8.4 \%$ over-dosing) and $37.3 \%$ with ibuprofen $(27.7 \%$ underdosing and $9.6 \%$ over-dosing). ${ }^{15}$ Turkish parents in this study (76.1\%) mostly/always used antipyretics when children were febrile. Underuse of antipyretics does not effectively reduce fever, it has been reported to increase parents' concerns about harmful outcomes from fever and overuse of health services; overdosing is potentially harmful. ${ }^{8}$

\section{Evidence-based childhood fever management}

Reports of evidence-based practices in Turkish parents vary over time. Beliefs about the benefits of fever were common in 1990s when most mothers surveyed (96\%) reported evidence-based beliefs, that fever in children was important $^{26}$ and that it was important for febrile children to drink water (75\%). However, few of these parents were aware that dehydration associated with high fever cause be harmful. In the early 2000s, Esenay and Yiğit found that only half the children admitted to hospital with a febrile illness had had sufficient fluids prior to hospitalisation. ${ }^{16}$ Later in this decade Celasin et al. ${ }^{21}$ found that most mothers $(81.1 \%)$ reported it important for febrile children to drink water, with half $(57.3 \%)$ understanding the rationale for this. Of concern is that the current study identifies parents' least likely practice to always ensure their child had plenty of fluids (30.2\%). This specifically related to parents living in cities, recruited through the hospital and those with university education. This highlights the need for individually targeted education about care of febrile children in preventing dehydration, particularly if parents administer ibuprofen to dehydrated children.

The need to observe febrile children for signs of deterioration is recognised as an important aspect of caring for a febrile child. ${ }^{27,28}$ Those recruited through the paediatric hospital reported this practice more frequently. This may reflect these parents' increasing concern precipitating taking the child to a hospital for medical assistance, greater concern than those seeking assistance in the community, from a family health centre.

Findings from this and the above studies highlight the variability in parents' practices and importance for Turkish health professionals to explore each parent's fever management practices and target education to reduce myths and non-evidence-based behaviours. Evidence-based guidelines have been developed specifically for parents use (http://guidance.nice.org.uk/CG160). ${ }^{27}$ Translation of these into Turkish and use in community and hospital settings may assist in reducing the unnecessary overuse for health services and antipyretic medications when children have a febrile illness.

With current practices in the Western world of alternating antipyretics ${ }^{3,4}$ it is imperative to explore this practice in Turkey to either address inappropriate practices or prevent the introduction of this potentially harmful practice in community settings. ${ }^{8}$ In addition to unnecessary medication of febrile children, antipyretics increase viral invasion, act against the body's natural defence against infection and extend the period of the illness. ${ }^{29}$ More recently prophylactic paracetamol was reported to reduce the antibody response following vaccination. ${ }^{30}$ When considered in context of the number of self-limiting viral illnesses in young children, it is imperative that Turkish parents' beliefs and practices be explored and corrected to reduce the overuse of antipyretics, over-the-counter medications, for simple febrile illnesses.

\section{Burden of caregiving}

Parental practices interfering with family life and potentially causing fatigue in parents of febrile children were common in our study. More than half the Turkish parents surveyed $(58.5 \%)$ always slept in the same room as their febrile child, they always took the child's temperature $(60.0 \%)$ and medicated the febrile child during the night (33.2\%). This indicates significant concern about fever, similar to the 'fever phobia' described by Schmitt in $1980^{31}$ and in Turkey by Esenay et al. ${ }^{16}$ In our study, about half the parents reported always taking their child to the doctor (53.7\%), 
confirming previous findings about health service usage for febrile children in Turkey by Ceceli et al. ${ }^{11}$ and Esenay et al. ${ }^{16}$

Fever phobic practices were responsible for unnecessary burden of caregiving, interference in family life precipitating parental fatigue when Turkish children had a febrile illness. Specific phobic practices were reported more frequently by parents from cities, university educated parents more frequently reporting taking their child's temperature than other parents. Those with a university education slept in the same room as their febrile child and woke them during the night for an antipyretic. Higher levels of education have previously been reported associated with fever phobic practices. 6,32,33

Through use of the PFMS-TR we identified a number of areas for parent education, education to specifically target unnecessary or non-evidence-based practices. Differences in the responses from parents from small towns and cities need further examination. Those related to recruitment centre may reflect the perceived degree of illness of their child at the time of survey. This study confirms the usefulness of this simple tool in community and hospital settings for clinicians to identify necessary parent education to not only reduce parents' burden of care when a child has a febrile illness but also promote evidence-based use of antipyretics and health services.

\section{Limitations}

This study was conducted in one area in Turkey with a small, through representative sample of randomly selected parents from differing socio-demographics. Generalisation of findings should therefore be undertaken with caution. There is a need for a large study of fever management practices of Turkish parents of both febrile and well children to identify education needed at a community as well as an individual level.

\section{Conclusion}

This study trialled the PFMS-TR in a sample of parents from villages, small towns and cities recruited through hospitals and family centres enabling comparisons to be made and supporting the instruments use in identifying areas where parents fever management education is needed. Further research is necessary to support the findings and enable the development of targeted educational interventions to support individualised parent education promoting evidence-based care of febrile children by Turkish parents. More trials of the original instrument in other countries and settings are needed to further test the instrument and identify education necessary to assist parents' care for their febrile children in an evidence-based manner, without undue interference in family life, reducing the current burden of care when a child is febrile.

\section{Authorship}

N.C., I.A. and S.S. designed, conducted, analysed the data and prepared a draft manuscript. A.W. assisted with data analysis and manuscript preparation.

\section{Provenance and conflict of interest}

There were no conflicting interests in either the development or conduct of this study. This paper was not commissioned.

\section{Funding}

No funding was sought to undertake this study.

\section{Acknowledgements}

The authors would like to thank the parents who participated in this study.

\section{References}

1. Knoebel EE, Narang AS, Ey JL. Fever: to treat or not to treat. Clin Pediatr 2002;41(1):9-16.

2. Poirier MP, Collins EP, McGuire E. Fever phobia: a survey of caregivers of children seen in a pediatric emergency department. Clin Pediatr 2010;49(6):530-4.

3. Walsh A, Edwards H, Fraser J. Over-the-counter medication use for childhood fever: a cross-sectional study of Australian parents. J Paediatr Child Health 2007;43(9):601-6.

4. Purssell E. Treatment of fever and over-the-counter medicines. J Emerg Med 2007;92(10):900-1.

5. Altun I, Cinar ND, Walsh A. Psychometric properties of the parents' fever management scale in a Turkish population. HlthMED 2011;5(3):567-75.

6. Walsh A, Edwards H, Fraser J. Parent's childhood fever management: community survey and instrument development. J Adv Nurs 2008;63(4):376-88.

7. Erkek N, Senel S, Sahin M, Ozgur O, Karacan C. Parents' perspectives to childhood fever: comparison of culturally diverse populations. J Paediatr Child Health 2010;46(10):583-7.

8. Sullivan J, Farrar H, Committee on Drugs. Fever and antipyretic use in children. Pediatrics 2011;127(3):580-7.

9. Bilenko N, Tessler H, Okbe R, Press J, Gorodischer R. Determinants of antipyretic misuse in children up to 5 years of age: a cross-sectional study. Clin Ther 2006;28(5):78393.

10. Kokki H, Kokki M. Ketoprofen versus paracetamol (acetaminophen) or ibuprofen in the management of fever: results of two randomised double-blind, double-dummy, parallel-group, repeated dose, multicentre, phase III studies in children. Clin Drug Investig 2010;30(6):375-86.

11. Crocetti M, Sabath B, Cranmer L, Gubser S, Dooley D. Knowledge and management of fever among Latino parents. Clin Pediatr 2009;48(2):183-9.

12. Nijman RG, Oostenbrink R, Dons EM, Bouwhuis CB, Moll HA. Parental fever attitude and management influence of parental ethnicity and child's age. Pediatr Emerg Care 2010;26(5):339-42.

13. Cohee LM, Crocetti MT, Serwint JR, Sabath B, Kapoor S. Ethnic differences in parental perceptions and management of childhood fever. Clin Pediatr 2010;49(3):221-7.

14. Arica S, Arica V, Onur H, Gulbayzar S, Huseyin D, Obut 0 . Knowledge, attitudes and response of mothers about fever in their children. Emerg Med $J 2012$, online first, http://emj.bmj.com.ezp01.library.qut.edu.au/ content/early/2011/12/08/emermed-2011-200352.full.pdf+ html?sid=e06b8e4a-464b-4b18-b0bf-ef6502a9b3dc 
15. Arikan Z, Teksam O, Kara A, Kale G. Determining causes and frequency of misdosing of antipyretics in patients presenting with fever to pediatric emergency. Turk Arch Pediatr 2012;47(2):114-8.

16. Esenay IF, İșler A, Kurugöl Z, Conk Z, Koturoğlu G. Annelerin ateșli çocuğa yaklașımı ve ateș korkusu. Türk Ped Arșivi 2007; 42:57-60.

17. SPSS for Windows, Version 15.0.1 [computer program]. Version 150. 1. Chicago, IL, USA: SPSS Inc.; 2006.

18. Polit DF, Beck CT. Essentials of nursing research: methods, appraisal, and utilization. Philadelphia: Lippincott; 2006.

19. Cohen J. A power primer. Psychol Bull 1992;112(1):155-9.

20. Avner JR. Acute fever. Pediatr Rev 2009;30(1):5-14.

21. Celasin NȘ, Ergin D, Atman Ü. Yüksek Ateș Șikayeti Ile Hastaneye Yatırılan 0-6 Yaș Grubu Çocukları Olan Annelerin Yüksek Ateșe ilișskin Bilgi ve Tutumları. Fırat Üniversitesi Sağlık Bilimleri Tıp Dergisi 2008;22:315-22.

22. Yaramis N, Arıtan S, Ișık Hva. 0-6 yaș grubu çocuğa sahip annelerin yüksek ateșe ilișkin uygulamaları. 29th UMEMPS Congress Union of Middle Eastern and Meditterranean Pediatric Societies, 49. Milli Pediatri Kongresi, 5. Milli Çocuk Hemşireliği Kongresi Özet Kitabı, İstanbul 2005;13:431-2.

23. Çınar DN, Sungur E, Çoğu N, Yürük M. 0-6 Yaș Grubu Çocuğu Olan Annelerin Vücut Isısı ölçümü ille illgili Bilgilerini ve Eğitimleri. Cocuk Forumu Dergisi 2001;4:42-4.

24. Langer T, Pfeifer M, Sounmez A, Tarhan B, Jeschke E, Ostermann T. Fear of functional - a crossectional survey of the concepts of childhood fever among German and Turkish mothers in Germany. BMC Pediatr 2011;11(41). http://www.biomedcentral.com/ 1471-2431/11/41 [accessed 15.08.12].

25. Alomar M, Alenazi F, Alruwaili N. Accuracy of acetaminophen dosing in children by caregivers in Saudi Arabia. Ann Saudi Med 2011;31(5):513-7.
26. Bektaș E, Kılıç M. 0-6 yașında çocukları olan annelerin ateșe ilișkin bilgi düzeyleri ve çocukları ateșlendiğinde evdeki uygulamalarının saptanması. Mezuniyet Tezi, İzmir: Ege Üniversitesi Hemșirelik Yüksekokulu; 1990.

27. National Health and Clinical Excellence (NICE), CG160 Feverish illness in children: assessment and initial management in children younger than 5 years. London, UK: National Instiute for Clinical Excellence; 2013.

28. El-Radhi AS, Carrol J, Klien N, editors. Clinical management of fever in chidlren. Heilderberg, Germany: Springer Verlag; 2009.

29. Plaisance KI, Kudaravalli S, Wasserman SS, Levine MM, Mackowiak PA. Effect of antipyretic therapy on the duration of illness in experimental influenza A, Shigella sonnei, and Rickettsia rickettsii infections. Pharmacotherapy 2000;20(December (12)):1417-22.

30. Prymula R, Siegrist C-A, Chlibek R, Zemlickova H, Smetana $J$, Lommel P, et al. Effect of prophylactic paracetamol administration at time of vaccination on febrile reactions and antibody responses in children: two openlabel, randomised controlled trials. Lancet 2009;374(9698): 1339-50.

31. Schmitt BD. Fever phobia: misconceptions of parents about fevers. Am J Dis Child 1980;134(2):176-81.

32. Aydin A, Ergor A, Ozkan H. Effects of sociodemographic factors on febrile convulsion prevalence. Pediatr Int 2008;50(2):216-20.

33. Matziou V, Brokalaki H, Kyritsi H, Perdikaris P, Gymnopoulou E, Merkouris A. What Greek mothers know about evaluation and treatment of fever in children: an interview study. Int $J$ Nurs Stud 2008;45(6):829-36. 